\title{
Spain and the European System (1820-23)
}

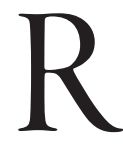

ESTORATION SPAIN'S POSITION IN the European alliance offered a bird's eye view of the challenges confronting political leaders during the first major insurrection of the Restoration era, and in Spain's American colonies, Enlightenment-inspired and popular movements had been ongoing since I808-10. In other words, the vulnerabilities and limitations of the European system, as conceived by Russia's monarch and diplomats in the years following the Congress of Vienna, appeared strikingly evident in Spain's relationship to the alliance and in the unstable political conditions engulfing the peninsula and colonies. Well before the great powers (with the exception of Britain) collectively recognized the Spanish Revolution as a threat justifying intervention, events in Spain began to disrupt implementation of the peacemakers' vision.

From the perspective of Russian diplomacy, an early challenge to peace in Europe appeared in Spain's refusal to accept the Final Act of the Congress of Vienna and the Second Treaty of Paris. Based on the treaties of 1815 , the duchies of Parma, Plaisance, and Guastalla belonged to the archduchess of Austria and wife of Napoleon, Marie Louise, and her descendants. Supported by Britain and France, Spain claimed that following the death of Archduchess Marie Louise, the territories should revert to the infante Marie Louise, daughter of the former Spanish king, Charles IV; her son, Charles Louis; and his direct male descendants. Despite the legality of Spain's claims and the importance of bringing Spain into the general alliance, Emperor Alexander hesitated to oppose Austrian interests. In the end, Austrian emperor Francis I accepted territorial adjustments proposed by Britain, and in July 1817, Spain acceded to the Final Act of the Congress of Vienna. ${ }^{1}$ Two years later, the General Act of the Frankfurt Territorial Commission (8/20 July I819) defined the line of succession to the Spanish infante, her son, and his male descendants. Exceptions included districts on the left bank of the Po, recognized as Austrian possessions, and the Principality of Lucca, which at the death of the Austrian archduchess would go to the Grand Duchy of Tuscany. ${ }^{2}$ 
Although Spain's acceptance of the Vienna settlement represented a crucial step toward securing the peace, a Russian overview of European politics, dated 5/17 June I817, highlighted additional problems. As happened repeatedly in the history of the alliance, among European governments suspicions about Russia's intentions abounded. ${ }^{3}$ In this instance, rumors of a special Russian-Spanish relationship called into question Emperor Alexander's commitment to the European system. The doubts seemed justified when by an agreement of $30 \mathrm{July} / \mathrm{II}$ August 1817 Russia sold warships to Spain. Not surprisingly, Alexander rejected the hostile characterization and even hinted that Britain should act as mediator between Spain and its American colonies. ${ }^{4}$ Russia's policy toward Spain, official statements contended, needed to be understood as part of a larger effort to strengthen the integrity (tselost') of Europe's general political system through moral influence. To restore the power of the Spanish crown, a process that had to occur in both hemispheres, Spain required assistance from all the European powers. To that end, Alexander's diplomats in Madrid received orders to communicate Russia's views to the Spanish king and his ministers, who should be urged to reach agreement with Britain about the slave trade and to accept British mediation in reconciling with the colonies. ${ }^{5}$ By the time the great powers met in Aix-la-Chapelle in September 1818, both of these suggestions had been accepted. ${ }^{6}$

Another source of concern arose from ongoing competition between Spain and Portuguese Brazil in the territory north of the Rio de la Plata. In 1816 Portuguese troops moved into the disputed territory of Uruguay, and in 1817 they occupied Montevideo, extending Brazil's frontier to the river. ${ }^{7}$ The five great powers unanimously condemned the attacks on Spain's American territories, and when the Spanish monarchy requested assistance, accepted the role of mediator in the interest of preserving the general peace. ${ }^{8}$ A note sent in February I817 from the ministerial conference in Paris to the government of Portuguese Brazil stated that refusal to accept mediation would be seen as definite proof of evil intent. The European powers recognized King Ferdinand VII's legal right to the territory but also wanted to make sure that in responding to the dispute Spain did not abandon the rules of moderation. According to the Russian overview of June 1817 , the success of the mediation effort remained uncertain, and by the time of the conferences in Aix-la-Chapelle, the conflict had not been resolved. ${ }^{9}$ Although the five great powers plus Portuguese Brazil accepted a British proposal for the restitution of Montevideo, in October 1818 Spain had not yet agreed to the plan. Nor did the Spanish monarchy succeed in reestablishing authority over the colonies. By 1825 the independence movements of Central and South America became effectively victorious, though as events unfolded 
and as the allies faced the harsh realities of revolution on the peninsula, the fate of Spanish America seemed less critical to the preservation of European peace.

\section{Early Responses to the Spanish Revolution}

When the revolutionary troubles began on the peninsula, neither rebellion in the colonies nor the conflict with Portuguese Brazil over Montevideo had been resolved. ${ }^{10}$ As the crisis deepened, Russian diplomacy focused less on the Spanish monarchy's relations with the colonies and more on the general problem of revolution in Europe. Documents of Russian provenance attributed the revolution in Spain to the government's lack of moral authority and to the persistence of the revolutionary spirit among sectarians and Jacobins. Here as elsewhere, Russia's diplomats called for political reform and good governance to combat disorder. In the mind of Emperor Alexander, support for constitutional reform, and sometimes even liberal principles, could be reconciled with the acceptance of absolutist monarchy. ${ }^{11}$ Even when Restoration governments experienced explosive political conflict over the meaning of principles such as constitutionalism and the rights of nations (or peoples), Emperor Alexander clung to a view of European politics based on strict legality (adherence to treaties) and Christian morality. In the monarch's thinking, calls for liberal reform did not assume the acceptance of a specific ideology or political system.

Two weeks after the mutiny led by Lieutenant Colonel Rafael Riego, Count Mark N. Bulgari, Russia's chargé d'affaires in Madrid, wrote to co-minister of foreign affairs Nesselrode about the weakness of the Spanish government and the boldness of the insurrectionists and their sympathizers. ${ }^{12}$ In contrast to the good order displayed by the rebel troops, the king's forces appeared demoralized and the monarchy paralyzed. Over the next few weeks, Bulgari's communications became increasingly critical of the Spanish government's inaction, the silence of the monarchy's defenders, and the failure of King Ferdinand VII to fulfill his promises of political reform. ${ }^{13}$ While acknowledging that a revolution had occurred, Bulgari also continued to argue that Ferdinand could salvage what had become a dangerous situation for all of Europe by announcing to his nation meaningful reforms. The Russian diplomat even went so far as to urge the king to call the Cortes and grant a constitution. The granting of constitutions by legitimate monarchs remained consistent with Russian policy, though on 7 March, when Ferdinand proclaimed the constitution of I8I2, he reportedly did so under duress to avoid the threat of violence. As Bulgari described the situation, the king had become a prisoner in his own palace. ${ }^{14}$ 
While Europe watched and waited, Russia's monarch and Ministry of Foreign Affairs held to the belief that the great powers acting in concert could preserve the peace. They also hoped to establish extraordinary forms of deliberation that would allow the allied monarchs to respond quickly and effectively to future emergencies. ${ }^{15}$ The Russian desire for collective action became more insistent after Ferdinand decided to accept the constitution. Thus, to ascertain what allied cooperation might mean, on 3/15 March 1820 Nesselrode wrote to Count Christoph Lieven, Russia's ambassador in London, seeking information on how the British government viewed the latest developments in Spain. ${ }^{16}$ According to Nesselrode, precisely because the spirit of insurrection had assumed diverse forms, the allies had an obligation to discuss confidentially how they would apply the moral force of the alliance to the revolutionary situation. Quoting a communication from Vienna, the co-minister identified several key principles: the intimate union (union intime) of the first courts; the spirit of benevolence animating the great monarchs; and the uniformity of their thinking and common experience, which kept at bay all political complications. Given the current crisis, did these principles still represent the cornerstone of the social edifice? To answer this question, Emperor Alexander wanted to know what measures the allies would take if: (I) the wisdom and energy of the Spanish government failed to suppress the volcano simmering under the throne; (2) the king of Spain sought assistance from his allies; or (3) the crisis continued in a manner that appeared more dangerous for the peninsula, the colonies, and the rest of Europe.

Austria's position, communicated to Nesselrode on $13 / 25$ April 1820 by Count Iurii A. Golovkin, recognized the threat of the Spanish insurrection, including the possibility of a massive revolutionary pact that could engulf the peninsula and the colonies. ${ }^{17}$ Even so, the Austrian government did not accept any allied responsibility to act. To date the Spanish king had not sought advice or help from the European powers. The Russian government acknowledged this reasoning but continued to press for a collective response. On I9 April/1 May I820, Nesselrode wrote to Golovkin, Lieven, and Alopeus (Russia's representatives in Austria, Britain, and Prussia) that Emperor Alexander wished to hold a meeting of the allies. ${ }^{18}$ Stability in France remained fragile, and now the fall of the Spanish government threatened disaster for all Europe. Again, Russia viewed allied unity, which had saved Europe from the French Revolution and Napoleonic conquest, as the best means to resolve the Spanish crisis.

Significantly, King Louis XVIII also appeared ready to discuss action in Spain, and the Russian government recognized France's right to take the initiative in negotiations concerning the Spanish monarchy. But based on alliance 
agreements, Alexander and Louis could discuss Spain only after Austria, Britain, and Prussia responded to the overture of $3 / 15$ March. ${ }^{19}$ Nesselrode therefore advised the French government to approach the other allies, without referring to Russia's memorandum, also dated 19 April/1 May, which called for allied action, if the Spanish government did not rectify the situation. ${ }^{20}$ As things turned out, Britain would consider collective action in Spain only if the royal family or the integrity of Portugal seemed to be in danger. ${ }^{21}$ Unable to respond to Russia's proposal with an official statement, due to internal political constraints and opposition to cooperation with France, Foreign Secretary Castlereagh nonetheless communicated to Count Lieven, and to the courts of Vienna and Berlin, that Britain remained committed to the general European system. ${ }^{22}$

Russia's memorandum to the allies arose from a note of 7/19 April 1820 addressed to Nesselrode by Spain's emissary in Saint Petersburg and future foreign minister, Francisco Cea Bermúdez (1779-1850). ${ }^{23}$ The note informed Emperor Alexander of Ferdinand VII's decision to accept the 1812 constitution and explained why he had done so. The king wished to provide security, tranquility, and harmony for his people, and he hoped to thwart insurrection by delivering happiness in the form of wise and stable institutions that corresponded to "the spirit and enlightenment of our time." Precisely because the Spanish people strove for freedom and the glory of the monarch, the king's action would unite the Spanish nation with the legal sovereign and therefore deserved the respect of the allies. The constitution of $\mathrm{I} 8 \mathrm{I} 2$ had been promulgated by the Cortes elected in I810, and the Treaty of Velikie Luki (8/20 July I8I2), which Russia had concluded with the anti-Napoleonic Central Junta of Spain, recognized the exiled King Ferdinand, the Cortes, and the constitution. ${ }^{24}$ Based on this treaty, the Spanish note proclaimed, Russian acceptance of the king's recent decision would rest on legal grounds.

Emperor Alexander responded to the Spanish appeal in a note of $18 / 30$ April 1820, addressed to Cea Bermúdez by Nesselrode. ${ }^{25}$ The monarch recognized that the prosperity of the Spanish state could not be separated from the glory of the king. In addition, one could argue that the events of March 1820 had become inevitable as early as I8I4, the year Ferdinand VII returned to the throne. Regardless, the illegal act that had subjected Spain to the rule of popular passions could not be justified. Russia had accepted the Treaty of 8/20 July i8 I2 out of respect, admiration, and gratitude for Spain's role in overthrowing the French yoke, sentiments shared by all the European powers. The allies also had shown ongoing concern for the fate of Spain, and Emperor Alexander himself repeatedly had expressed the hope that through legal rules and wise state constitutions the power 
of the Spanish king in Europe and America would be secured. But in order to strengthen the state, political reform had to be a gift from the government. As history and experience proved, changes arising from disarray and anarchy led to ruin, not happiness. The Spanish government still had time to correct the situation; however, the constitution, established by violence and revolution, could not be accepted. The current danger to Spain affected all the European powers, and Alexander needed to confer with the allies before pronouncing on the events of 7 March. ${ }^{26}$ To facilitate deliberations, he asked the Spanish government to address the allies as he had been addressed. In other words, from the moment of Ferdinand VII's initial solicitation, Alexander insisted on responding to the Spanish crisis in concert with allied governments. The Russian government held to this position until the conferences in Verona finally produced agreement on supporting a French intervention.

The memorandum approved by Emperor Alexander on I9 April/r May I820, which Austria and Britain later refused to endorse, described the exchange of notes with Cea Bermúdez. ${ }^{27}$ Although the Spanish government sought a statement from Alexander on the political changes of 1820 , the monarch did not want to act independently of the powers adjacent to Spain and therefore in a better position to judge the threat to that country. Indeed, precisely because the revolution contained seeds of development that might become critically important for all educated peoples, it had attracted the attention of leaders in Europe and the New World. Certain to have a global impact, the revolution demanded a timely response. Otherwise, ill-intentioned men would use the uncertainty as a weapon to further their goals. To prevent this, Alexander wished to make a pronouncement on the unfolding crisis, which he hoped the allies would approve. As the memorandum clearly stated, the monarch wanted his position on Spain to be consistent with "the general principles (pravila) of European Policy."

How did Emperor Alexander understand European policy? In 1812 the allied monarchs had taken an interest in the fate of Spain and admired the heroic struggle of the Spanish people against the foreign foe. At the time, they had viewed the constitution as the best way to unite the nation and preserve its political independence. Even after Divine Providence returned Ferdinand VII to the throne, the allies continued to believe that wise and firm institutions were needed to improve the foundations of the old Spanish monarchy. Thus, during discussions related to pacification of the colonies and the conflict with Portuguese Brazil, the allies tried to impress upon Spain's rulers that political reform would lead to prosperity and calm, only if the people perceived the changes as a free gift emanating from the goodwill of the government. If, by 
contrast, the government appeared to institute change under duress, in an act of self-preservation, the reform would be seen as evidence of weakness.

Following the events of 7 March, the allies generally assumed that the revolution in Spain represented a direct threat to France. Although the protocols of Aix-la-Chapelle (3/15 November 1818) had aimed to eliminate the last traces of the French Revolution, the destructive spirit of the revolutionary evil had survived and now attacked Spain, once again obligating the monarchs to confront political upheaval. Sadly, the allies expected that rebellion in Spain would be no less horrific than it had been in France. Describing 1820 as an unlucky time, Emperor Alexander nonetheless hoped to see the formation of a Spanish government capable of restoring order. But regardless of how conditions in Spain developed, he expressed confidence that the allies would approve Russia's response to Cea Bermúdez and therefore felt compelled publicly to declare opposition to the illegal means employed to introduce the new Spanish institutions. Perhaps, the Russian memorandum suggested, the allies already had sent similar notes to the Madrid court. Indeed, Alexander believed that the unity of wishes and principles defining the alliance inevitably produced likeminded opinions. Thus, the allied monarchs shared the opinion that illegal actions always led to disastrous results, in this case not only for the Spanish nation but also for Europe as a whole.

Because European governments had reacted with sorrow to the new crime imposed on Spain by the rebels, the Russian memorandum suggested a possible solution to the calamity. The best outcome would be for the Spanish nation to offer the peoples of the world an example of repentance. Simply put, Spain could reconcile with the other powers of Europe by rejecting revolution. With respect to the change of government, the interests of Europe and the Spanish Cortes actually coincided. Because the troops protecting the Cortes could rebel at any moment, it was in the interest of the Spanish monarch, fatherland, and legislative assembly to demonstrate that insurrection would not be recognized as legal. The Russian emperor did not expect this to happen, but he did argue that the moral force of unanimous opinion among the great powers, especially concerning the duty of the people's representatives, might bring about the desired result. The diplomats of the five great powers should therefore communicate to Spain's plenipotentiary in Paris their concern for the fate of the Spanish people. Tranquility and prosperity for all Spaniards, the memorandum stated, could be secured by establishing through legal means new institutions in Europe and Spanish America-institutions that corresponded to "the needs of the time and the successes of Civilization (Grazhdanstvennost')." 
At this juncture, in both Spain and Spanish America, institutional reform no longer seemed sufficient to counter insurrection. For the salvation of Spain and the benefit of Europe, the Spanish government also needed to repress and denounce insurrection. Significantly, the Russian government viewed the Cortes as part of the solution. Perhaps because King Ferdinand had called the Cortes before taking the oath to the constitution, and because of the assembly's ancient origins, Russian officials distinguished the actions of the revolution from the legitimacy of the Cortes, even though its powers, based on the $18 \mathrm{r} 2$ constitution, continued to pose a problem. ${ }^{28}$ The Cortes possessed the legal authority to establish constitutional forms, as long as this was accompanied by the strictest prohibitions against rebellion. In these circumstances, the allied courts could remain in relations of friendship and trust with the Spanish government, without having to violate their own shared principles. In other words, if the Spanish government heeded the allies' advice, they would be able to declare the revolution at an end. The Cortes in turn would need to pledge obedience to the king in the name of the nation and find a way to establish internal tranquility and order on the peninsula and in the colonies. If these hopes were not answered, however, and Spain remained in the current state of anarchy and riot, at least the allies would have fulfilled their sacred duty and demonstrated "the true principles, purpose, and form of action of the great European alliance." ${ }^{29}$

Russia's diplomats had responded quickly and emphatically to the events of 7 March, yet without advocating intervention or action outside the great European alliance. ${ }^{30}$ Aleksandr S. Sturdza's correspondence with co-minister of foreign affairs Ioannis Kapodistrias illustrated the confusion and conflicting impulses that found their way into Alexander I's thoughts on the Spanish Revolution. In a dispatch of 24 April I820 (NS), which reportedly influenced the memorandum of 19 April/s May, Sturdza wrote that in Spain the system of liberal ideas had reached its apogee and therefore must either retreat or produce new explosions. ${ }^{31}$ Equally disturbing, the Spanish king had become a slave to plebian tyrants. Unable to marry or abdicate without the permission of the Cortes, he had been deprived of his dignity in the eyes of foreign powers. In other words, the liberal furor in Spain had reached the highest degree of absurdity, rendering retreat the only appropriate option.

But how would the retreat of the revolution unfold? Sturdza assigned significant blame for the current crisis to the Spanish monarch. A power restored to its rights after great disturbances needed to legislate in order to revive the old institutions. Sadly, King Ferdinand VII, lacking both a domestic and a foreign policy, had promised reform but not delivered on his pledge. Instead, 
he had abdicated the right to control the process of reform and become a king who humbly recognized "all the Acts of popular Authority." Sturdza went on to describe his own vision of how Ferdinand should proceed with reform. The restoration of ancient institutions demanded legislation that rested "on a more or less perfect harmony of faith, science, and Authority." Such legislation could guide the government in addressing the primary causes of revolution: irreligion, injustice, and insolvency. Specifically, the Spanish government needed to make public education religious, invigorate police administration, and wisely administer public wealth. None of this had been accomplished, and although Russia had not yet experienced the consequences of revolution, the moral contagion could easily spread, especially in an age of intensified contact between nations. Sturdza did not believe that congresses or repressive alliances could stop the principle of revolution, but he did insist that governments should respond with force and vigilance to the earliest manifestation of this electric jolt.

Despite Sturdza's strong prescriptive rhetoric, his dispatch and other correspondence admitted outright that the crisis in Spain had become difficult to understand. He rejected the fact of revolution as legitimate grounds for intervention in Spain's internal affairs. He did argue for a formal declaration of the allied courts, based on international law (le droit des gens). The constitution of I812 denied the sovereign authority of the king, meaning that it violated rights universally recognized by all European peoples. ${ }^{32}$ Nor, Sturdza insisted, could any single policy effectively combat revolution; different policies were needed in different countries. ${ }^{33}$ This argument blended with Alexander I's belief (and hope) that allied unity, particularly unity of principle, would ensure the preservation of peace, which revolution inevitably threatened (as shown by history and experience). Sturdza described the Russian monarch's reaction to the Spanish Revolution as profound sorrow. ${ }^{34}$ Unfortunately, profound sorrow did not move the allies to act.

Faced with allied inaction, Russia's diplomats continued to argue that domestic reforms could save Spain from the consequences of revolution. ${ }^{35}$ Persistent calls for reform suggested that the king might still be able to assert control over the revolution, which then could turn into legal political change. In June and July 1820 , diplomatic communications revealed just how complicated, dangerous, and incomprehensible the situation appeared. ${ }^{36}$ By July reports of violent resistance to the constitutional system and the government in Madrid reached the Russian Ministry of Foreign Affairs. Writing from Paris, General Karl O. Pozzo di Borgo, Alexander I's minister plenipotentiary, described the intimate union between the Cortes and king as Spain's only hope for peace. By contrast, 
a royalist reaction that the king did not direct would lead to civil war. Count Bulgari's reports, which previously had described King Ferdinand as a prisoner, seemed to become more optimistic. In communications of I4/26 June and 21 June/3 July 1820, he depicted the preparatory work of the Cortes as orderly and the discussions among the deputies as moderate. Despite hints of opposition from Spanish Americans, the inclusion of thirty substitute deputies to represent America and another three to represent Cuba suggested to Russian officials that the crisis might be headed for resolution.

\section{The Spanish Revolution and the Colonies}

Inaction also remained the allied approach to Spanish America. Both before and after insurrection hit the peninsula, political conditions in the Spanish Empire created problems for the European alliance. Rebellion in Spain's American colonies began as early as I808-IO, and the Spanish troops that mutinied on I January 1820 were awaiting embarkation to South America. Although Spain's relationship with the colonies did not necessarily represent a European concern, the allies began to discuss possible solutions prior to the conferences in Aix-la-Chapelle. The Russian government accepted the Spanish monarchy's view of the colonies as provinces of the metropolis and hoped that in Spain and Spanish America the establishment of wise institutions, including policies tailored to the specific needs of different territories, would ensure peace, stability, and the preservation of King Ferdinand VII's authority. The allies, particularly Britain, might act as mediators, though in contrast to Russia, which in 1817-18 sold warships to Spain, the British government refused to countenance the possibility of armed intervention. Equally troubling, the diplomatic effort to achieve pacification through mediation failed to win consistent support from the Spanish monarch. In October I817, Ferdinand rejected Britain's proposal for allied mediation on the grounds that it did not require the rebellious colonies to accept his sovereignty. ${ }^{37}$ Russia's envoy in Madrid, Dmitrii P. Tatishchev, agreed that the British proposal did not show sincere interest in the cause of Spain. ${ }^{38}$

Allied discussions about how to pacify Spain's rebellious colonies and resolve the conflict with Portuguese Brazil over the Rio de la Plata continued in 1818 and 1819. At the conferences in Aix-la Chapelle, the five powers, acting as conciliators rather than arbitrators, urged the Spanish and Portuguese monarchs to reconcile. ${ }^{39}$ On the question of pacification, the government in Madrid seemed to want allied mediation and to assume that the five great powers would provide moral support for the Spanish position. Although France and Russia did not 
reject outright the use of force on behalf of Spain, Britain's opposition to military intervention remained firm. Castlereagh, supported by Metternich, pressed for a collective declaration urging Spain to accept mediation and insisting that any allied action be pacific. Kapodistrias, as reported to Emperor Alexander by Nesselrode, criticized the idea of announcing in principle the impossibility of military assistance, arguing that this would only embolden the rebels. Better, the co-minister pleaded, to insist that the Spanish government explain its plans for pacification. Russia's diplomats accepted the reality of allied differences over support for Spain, and Kapodistrias even suggested that uncertainty about the intentions of the great powers could inspire salutary disquiet among the insurgents. But Kapodistrias also admitted that the allies lacked sufficient knowledge of "the real state of America and the circumstances of the insurrection to be able to judge the efficacy of the remedies that they might like to employ to stop the progress of the evil." Russia preferred to act within the alliance and during the negotiations withdrew support for a French-authored memorandum that implied the use of force. Prussia remained silent, a posture that Castlereagh interpreted as support for the British position. Given that Spain was not admitted to the conferences, France also declined to express an opinion on Castlereagh's proposal. ${ }^{40}$

The discussions in Aix-la-Chapelle produced no action on the question of pacification, and as Emperor Alexander made clear to Ferdinand VII in a December communication, military cooperation by the intervening powers to assist Spain in the work of pacification was in fact impracticable. ${ }^{41}$ Historians also report that in December Ferdinand again rejected foreign involvement, this time explicitly. Notwithstanding the apparent finality of the monarch's statements, from the end of 1818 through March 1819 , Russia's diplomats continued their efforts to persuade the Spanish king to accept British mediation. ${ }^{42}$ As noted in a dispatch from Kapodistrias to Tatishchev, dated ${ }_{13} / 25$ December 1818 and approved by Alexander, in 1815 Spain had placed itself outside the circle of European relations. ${ }^{43}$ "Barely restored to its independence, poorly consolidated in its internal relations, damaged in the administration of its colonies, this power. . wanted to be isolated from all the other States with the intention perhaps to become itself the center of a political system." Indeed, in refusing to accede to the Final Act of the Congress of Vienna, Spain had articulated outdated pretentions incommensurate with the country's "effective weight ... in the balance of the great interests" of Europe or Spanish America (the other hemisphere).

Although Alexander tried to impress upon King Ferdinand the importance of cooperation with all the powers, based on the conservative principles currently regulating European politics, the Spanish government seemed to assign 
primacy to relations with Russia. This created tension within the alliance, prompting Kapodistrias to admit that Spain's erroneous ideas about a special relationship with Russia also led to equally false opinions about the influence of the Russian mission in Madrid. These opinions in turn fueled the arrogance of Spanish pretentions in the matter of the Rio de la Plata and in talks concerning the pacification of the colonies. Emperor Alexander hoped to see a prompt and real reconciliation between the courts of Spain and Portuguese Brazil, according to "the principles of an equitable reciprocity," which then could lead to "the most perfect agreement of views and action in the pacification of the other hemisphere." But instead, the Spanish government equivocated in relations with the Portuguese and temporized in dealings with the mediators. With respect to colonial affairs, Spain continued to seek from the allies "the promise or at least the prestige of military cooperation, in order to bring the colonies back to the mother country."

Together with the direct communication sent to King Ferdinand by Emperor Alexander, Tatishchev received instructions to explain to the court of Madrid the conclusions reached in Aix-la-Chapelle on the matter of the colonies. Regardless of the king's desire for armed cooperation, the Spanish government needed to understand that any allied intervention would require a formal invitation from Ferdinand addressed to the five powers. Equally important, cooperation with the allies could not be military, as a matter of principle for Britain and of impracticability for the other courts. ${ }^{44}$ Finally, allied cooperation to restore Spain's legitimate power carried conditions. The government in Madrid needed to convince the peoples of the mother country and colonies that reunification would place them "under the permanent safeguard of a liberal policy (systeme)," accorded to them by the Spanish government. The policy of benevolence must be applied quickly to the colonies, so that the paternal voice of their legitimate sovereign could once again exercise a happy empire.

Assuming that King Ferdinand took the steps set forth in Tatishchev's instructions, Spain would be able to embark on the great work of pacification either without foreign cooperation or with friendly assistance from Britain, specifically negotiations led by the Duke of Wellington through the collective intervention of the other four powers. The purpose of this intervention would be to develop a plan for pacification supported by the five great powers and Spain. Indeed, the moral pressure exerted on the insurgents by allied unity would represent a more effective guarantee of promised reform than the actions of any single power. ${ }^{45}$ Russian diplomats may have been justified in criticizing Ferdinand (or his subalterns) for a policy based on false ideas and mistaken opinions, but the 
historian also can understand Spain's refusal to submit to the judgments of the five great powers - powers that in this instance expected deference from the rulers of a centuries-old metropolis and a people repeatedly praised and admired for their resistance to Napoleonic conquest. Not surprisingly, in rejecting mediation Spanish officials deployed the language of friendship among the sovereigns to assert Spain's equal status vis-à-vis the great powers. ${ }^{46}$

Tatishchev's representations to King Ferdinand VII and his minister of foreign affairs, Carlos-Maria-Martinez Casa Irujo (the Marquis of Casa Irujo), continued in January and February I819. Repeatedly, the Russian envoy reported to Nesselrode, he had attempted to apply to discussion of the colonies "the policy of conciliation introduced into the mutual relations of the European powers. ${ }^{\text {"47 }}$ Try as he might, however, the effort to persuade Spain to accept the allies' conditions and begin a process of mediation had failed to elicit the desired response. Equally troubling, Tatishchev's colleagues, the ministers of the other great powers, did not seem to care about engaging the Spanish authorities in a discussion of Europe's general interest or of allied unanimity on this important question. Writing directly to Emperor Alexander on 30 January/ı February i819, Tatishchev described ongoing frustration at his inability to fulfill the mission entrusted to him. ${ }^{48}$ Ferdinand VII refused to accept mediation by Wellington, a course he characterized as "perilous for Spain and humiliating for his person." Tatishchev agreed that British and Spanish interests appeared irreconcilable, primarily because Britain sought only to separate Spain from Europe. Tatishchev also complained of diplomatic intrigue directed against him and even his wife, a situation he attributed to allied suspicions about Russia's ties to Spain and jealousy arising from his close personal relationship with Ferdinand. Feeling isolated and ineffective in the fulfilment of his duties, Tatishchev requested reassignment.

In a report to Nesselrode, dated one day after the appeal to Alexander, Tatishchev elaborated on the reasons for his inability to convince Ferdinand VII to accept Wellington's mediation. ${ }^{49}$ Discussions in 1817 and 1818 , prior to the conferences in Aix-la-Chapelle, had indicated that the Spanish government hoped to work with Portuguese Brazil to end the insurrection in the colonies. Spain also had seemed willing to make concessions based on earlier British proposals: a general amnesty for all insurgents, the admission of qualified Americans to positions and rewards currently monopolized by European Spaniards, the application of liberal principles to trade between the Spanish American provinces and foreign states, and sincere consideration by the Spanish king of other measures that might be proposed by the allies, as long as they were compatible with the maintenance of his rights and his dignity. ${ }^{50}$ Whatever the promises 
contained in the plan for pacification, Britain eventually concluded that it did not justify formal negotiations. In addition, it became clear that Spain intended to use mediation to secure meaningful cooperation from the allies.

Despite obvious disagreements, in July I818, Tatishchev still expected King Ferdinand to follow the suggestion that the political and civil regime of the colonies be assimilated into that of the metropolis. Russia hoped that Spain would announce this policy as the basis for administrative reforms in the colonies and present the plan for pacification to the allies meeting in Aix-la-Chapelle. King Ferdinand then would negotiate the plan's implementation. In the summer of I8I8, according to Tatishchev, the Spanish government continued to look to Britain for support in achieving its goals. But during the conferences in Aix-la-Chapelle, Ferdinand suspended the discussion of foreign intervention in the affairs of the colonies. Changes in the composition of the Spanish government had led to a reappraisal of British policy and to the realization that British interests were opposed to those of Spain with respect to the Bourbon restoration(s), international trade, and Spanish American independence.

Citing communications from Casa Irujo and Cea Bermúdez, Tatishchev offered a sympathetic description of Spanish policy prior to and during the conferences in Aix-la-Chapelle. In the Restoration era, the Spanish government's primary obligation was "to reconstitute the power of Spain for its internal happiness" and to give the country the forces required to become a truly independent power, "useful in the active system of political equilibrium." To fulfill this destiny in the system of European states, Spain's ministers had surveyed the resources that would be needed to recover the colonies and their availability on the peninsula. Balancing the use of these resources with the losses that the colonies' independence would bring and recognizing the "just value of the moral and material means of resistance" that the insurgents could mobilize, the Spanish government had concluded that sacrifices would be unavoidable if Spain wanted to reestablish relations of patronage with America. Thus, the process of pacification envisioned by Spain, as described by Tatishchev, would need to consolidate the metropolis's power through clemency and moderation. This would require that imperial authority be restored through strength and compromise with the commercial interests of other nations, assuming such compromise did not mean suicide for Spain. In other words, Spain had decided to rely on its own wisdom and energy to pacify the colonies without the complications of foreign involvement. Following the conferences in Aix-la-Chapelle, and despite direct communication between Alexander I and Ferdinand VII, Tatishchev's ongoing effort to encourage pacification within the framework of the alliance had led to naught. 
Because both Britain and the United States had interests, opinions, and a public mood that worked against Spain's royal cause, Tatishchev considered British participation in the pacification to be essential. This led to the final effort to persuade Spain to accept mediation headed by the Duke of Wellington and to the announcement that military cooperation between the allies and Spain would not be an option. In responding to Tatishchev, the Spanish government showed a complete lack of confidence in both the efficacy of British mediation and the impact of a morally united alliance. The commercial interests of Britain, King Ferdinand insisted, made it impossible to offer sincere assistance to Spain. Nor did the Spanish government observe any positive results from the ongoing diplomatic negotiations with Portuguese Brazil. Alexander's suggestion that Ferdinand should choose the moral support of all Europe over his own isolated efforts failed to dispel Spanish distrust of allied advice. As Ferdinand remarked to Tatishchev, "I hope that you will never recommend to me an act of weakness." 51

Tatishchev remained in Madrid, and by the end of March I819 (NS), he at least could report that the British government now appreciated his efforts to convince Spain to accept the allies' offer of mediation. ${ }^{52}$ At the same time, he made clear that it would be pointless to engage in further conversations with the Spanish government concerning pacification of the colonies. The Paris conference of ministers continued to discuss the conflict over the Rio de la Plata, and despite Ferdinand VII's suspicions about the negotiations, Tatishchev still hoped that Spain would accept the agreement with Portuguese Brazil proposed in August $1818 .{ }^{53}$ In general, Russia's diplomatic communications held out the possibility of resolution in both the conflict over the Rio de la Plata and the pacification of the colonies. Still, the Ministry of Foreign Affairs also repeatedly seemed to admit defeat. As Nesselrode explained in a circular dispatch of $3 \mathrm{I}$ March/12 April I819-addressed to Russia’s ambassador in London (Lieven), envoy in Vienna (Golovkin), envoy in Berlin (Alopeus), and minister plenipotentiary in Paris (Pozzo di Borgo) - in Aix-la-Chapelle the allies had agreed to support mediation between Spain and its American colonies led by the Duke of Wellington, should Spain recognize the inadequacy of the resources at its disposal. ${ }^{54}$ In this scenario, Wellington would preside over the formulation of a plan for pacification appropriate to the needs and wishes of Spanish America, while the ministers of the other powers would mediate between Britain and Spain, to ensure Madrid's deference to the intervening courts and to place just limits on cooperation with the British government.

Tasked with explaining to the Spanish government the allied plan, Tatishchev had tried but failed to obtain acceptance of the proposed mode of intervention. 
Spain had refused all foreign involvement, preferring instead to rely on its own resources to reconquer its colonies. The Russian government had expected this response and considered it consistent with "the respect that European policy accords to the independence and dignity of all governments." Yet as Tatishchev also pointed out, Spain's wish to rely on its own forces, which would be appropriate for a great power, rested on dangerous illusions rather than positive facts. Emperor Alexander therefore hoped that Spain would evaluate its real resources correctly. In America, for example, Spain could augment these resources through a generous and liberal administrative system, capable of rallying to the cause of legitimacy "all interests and consequently all desires." The Russian monarch wished his fellow sovereign success in the enterprise that lay ahead, though he also could not help but lament Ferdinand's rejection of collective allied assistance. ${ }^{55}$

At a moment when religion and morality supposedly guided European policy, and when unity and peace reigned in the conservative system, Spain's relationship to the great powers, the Portuguese monarchy, and the Spanish American colonies exposed the potentially disruptive dynamics of the post-Napoleonic equilibrium. Delusional, ineffective, and reactionary as the Spanish monarchy appeared, the five great powers, presuming to speak on behalf of all Europe, were equally unrealistic about their ability to mold lesser powers and complicated historical processes into their vision of European peace. Perhaps in the allies' unwillingness to offer military assistance to Spain, they admitted to this inconvenient fact. With respect to Spain and the Spanish Empire, the imagined juste milieu of harmony, tranquility, and stability in the Restoration era produced barely a moment of peace. ${ }^{56}$

Following the conferences in Aix-la-Chapelle, preservation of Spanish authority in the Americas ceased to be an allied obligation. Yet throughout I819 the Russian government continued to hope that political reform emanating from the Spanish government would lead to reconciliation. Just days after the military rebellion that marked the start of the Spanish Revolution, Emperor Alexander again proffered advice to King Ferdinand concerning Spain's relations with Portuguese Brazil and the desirability of administrative reform for all the monarchy's subjects. ${ }^{57}$ Speaking for the Russian monarch, Tatishchev conveyed Alexander's feelings of friendship toward Ferdinand and his interest in the prosperity of the king's realm. For the moment-news of the January mutiny had not yet reached the Russian government-the issues at hand remained the conflict over the Rio de la Plata and the reestablishment of durable relations based on unity and reciprocal assistance between Spain and Spanish America. 
The first action recommended to King Ferdinand by Emperor Alexander was to restore friendly relations with the court of Portuguese Brazil. Since at least I815, Alexander I had viewed the concept of Christian brotherhood and friendship among the sovereigns as critical instruments of peacemaking. In this instance, the monarch expected friendship between the Spanish and Portuguese kings to produce a solution to the conflict over the Rio de la Plata. Friendly relations between Spain and Portuguese Brazil also would highlight Ferdinand's good intentions toward the people and therefore exert a favorable influence on his American subjects. More concretely, Alexander advised his fellow sovereign to equalize the rights of all Spaniards in both hemispheres. Uniform administration would guarantee the security of person and property that was needed to undercut the grievances invented by rogue and anarchic spirits.

As time passed, the Russian government's hopes for a Spanish restoration in the Americas receded, especially after the peninsula descended into revolution and civil war. Two detailed memorandums preserved in the papers of co-minister of foreign affairs Kapodistrias illustrated official Russian thinking on the colonies during the early months of the Spanish Revolution. The first document, dated March 1820, began with an account of the insurrection in Spanish America during the years 1808 to 1817.58 The named causes included recognition of Joseph Bonaparte as king of Spain, the weakness of the Spanish viceroys who administered the colonies, British policy, and enmity among the leaders and judicial officials operating in different territories of Spanish America. Conditions on the peninsula likewise caused problems: the uncertainty surrounding royal authority, resistance to Ferdinand VII and to Napoleon, French military success, the audacity of political factions, and disorder within the Napoleonic government. The memorandum went on to survey the patterns of insurrection in various parts of Spanish America, where loyalists, legislatures, and separate jurisdictions competed for power and legitimacy. Above all, the memorandum highlighted the loss of political resources brought on by the revolutionary explosion in Spain. Absent the crisis on the peninsula, the ordinary causes of disorder would not have been sufficient to fuel rebellion in Spanish America.

The author of the memorandum attributed persistent rebellion to the precarious condition of Spain that had begun with the Napoleonic invasion in 1808 and continued until the return of King Ferdinand VII in I8I 4. Based on the lessons of history, the maxim that every revolutionary movement invariably produced another explained the simultaneity of the uprisings across Spanish America. As royal authorities tried to maintain neutrality in the struggle between Napoleon and the defenders of Ferdinand, demagogues and factions used the political uncertainty 
to spread their influence. The memorandum described the Spanish American insurrections as the work of propertied classes and elites of birth engaged in a vast conspiracy. In other words, the revolts did not represent a popular movement or "great political revolution founded on principles." Nor, despite the participation of subalterns, did the American revolutionary scene embody the suffering of a people who demanded change. To the contrary, the troubles in Spanish America arose from an anarchic operation that renounced order and concord.

The second memorandum, dated 30 April/12 May 1820 and attributed by historians to Kapodistrias, offered a more pointed analysis of Spanish America, in light of the reestablishment of the constitutional system in Spain-the same system that had existed in I8I 4 at the time of Ferdinand VII's restoration to the Spanish throne. ${ }^{59}$ Given the events of March 1820 , how could the union of Spain with its old American possessions be strengthened? Describing Spanish America as a hybrid society, Kapodistrias highlighted the relationship between Spain's political interests and the future of Spanish America. The revolution in Spain had changed the meaning of political alignments in the colonies and might offer a solution to the problem of pacification. Although freedom of the press in places such as Mexico, Peru, and Cuba deprived Spain of an authority fortified by "the enlightened compression of partial dissent," the Cortes now had the opportunity to enact equitable legislation on the rights and duties (devoirs) defining commercial relations between Europe and the colonies. Kapodistrias imagined a relationship between Spain and Spanish America similar to the one that had existed between Britain and the North American colonies in 1775 (before the Declaration of Independence). He also argued that in the current situation the government in Madrid should make sacrifices to achieve reconciliation with the colonies. Although some of Kapodistrias's comments could be interpreted as support for constitutional restoration, his overall analysis adhered to the principles of Russian foreign policy. Throughout the peacemaking of 1814 to 1823 , Emperor Alexander's diplomats responded to the upheavals in Spanish America and later to the revolution in Spain with calls for enlightened reform granted by the legitimate monarch, Ferdinand VII.

The vision of reform from above, a product of enlightened monarchy across Europe, made it difficult for peacemakers to adapt the legal stipulations of I8I 4, I8I5, and I8I8 to the reality of open political contestation. Simply put, their vision of harmoniousness, stability, and transformation could not contain the social and political changes underway in Europe or the Americas. As the Spanish American independence movements, the Greek insurrections, and the Russian-Ottoman war scare of $182 \mathrm{I}-22$ all illustrated, the suppression of revolution, 
understood to be essential to the preservation of peace in Europe (and effectively carried out in Italy, Portugal, and eventually Spain) did not depend entirely on developments within the boundaries of Europe. European order had become a transatlantic, transpacific, and transcontinental affair. In March i822, the United States recognized Spanish American independence in principle, and by December the Russian government admitted that emancipation appeared inevitable, even if it was not yet imminent. ${ }^{60}$ Indeed, when emancipation came, Russia did not immediately recognize the newly independent states. In other words, the opaque and contradictory response of Russia's diplomats to the insurrections in Spanish America highlighted the ongoing failure to understand that liberalization had become inevitable. In keeping with eighteenth-century discussions of political dissent and religious toleration, Russia's rulers continued to assume that a handful of instigators - or in post-Napoleonic Europe, a faction of revolutionaries, sectarians, or Jacobins - was responsible for the persistent disorders. As historians document for multiple aspects of Russian political culture, the reliance on personalized relationships of authority meant that disorder and corruption represented individual rather than institutional behavior. Consequently, the solution to inequity and abuse was not systemic reform, but the moral self-reformation of subjects, citizens, and officials.

\section{The Verona Conferences and the Spanish Revolution}

During the initial phase of the Spanish Revolution, stretching from the military mutiny of January I820 until early March, when King Ferdinand VII accepted the I8I2 constitution, Emperor Alexander I tried to reach agreement with the allies on a collective European response. The effort failed, though after the conferences in Troppau and Laibach sanctioned Austrian intervention in Italy, Russia's policymakers again dared to hope that Britain and France would join the effort to save Spain. Writing from Laibach to Russia's chargé d'affaires in Madrid, Count Bulgari, co-minister of foreign affairs Kapodistrias expressed the view that restoration in the Kingdom of the Two Sicilies, by illustrating the effectiveness of allied action, could lead to the same result in Spain. ${ }^{61}$ Alexander agreed and supported intervention, but only with French participation and British acquiescence. In the meantime, the monarch continued to instruct his diplomatic representatives to maintain a posture of neutrality. ${ }^{62}$

By the time the Verona conferences opened in October 1822, developments within the alliance, especially the three monarchs' accession to the Troppau protocol and successful restorations in the Two Sicilies and Piedmont, combined 
with events in Spain to produce a new calculus among the allies. Of particular concern, the government in Madrid, still crowned by Ferdinand VII, appeared to take a more radical position on the question of revolution outside Spain's borders. From January I82 I, before the Austrian military intervention in Naples, the Spanish government reportedly had come under domestic political pressure to support revolt in other parts of Europe. Notwithstanding proclamations of neutrality from officials in Madrid, it looked as if Spanish diplomats had become involved in revolutions in Italy and Portugal. In addition, although both the Spanish king and government claimed to support implementation of the 1812 constitution, debates in the Cortes revealed that some political leaders viewed allied action in Naples as the precursor to intervention in Spain. Finally, in July I822, fear of a counter-revolutionary conspiracy inside the king's guard led to disorders that brought Spanish radicals to power. ${ }^{63}$ These developments pushed the French government to side with the legitimist alliance and the allies to view King Ferdinand as a prisoner to be saved. ${ }^{64}$

On 20 October 1822 (NS), the day the Verona conferences opened, the French foreign minister, Vicomte Mathieu de Montmorency (1767-1826), delivered a confidential verbal note to the plenipotentiaries of Austria, Britain, Prussia, and Russia. The Russian response to Montmorency's communication, which described an imminent threat to France emanating from Spain, began with an overview of Alexander's position on the Spanish Revolution. ${ }^{65}$ Since April 1820 the Russian government had expressed concern about the situation in Spain and had encouraged the allies to show benevolent solicitude for the Spanish nation, which deserved to enjoy happiness after the glorious struggle against foreign rule. Russia had hoped to prevent the misfortunes that inevitably resulted from violent attacks on legitimate authority. But sadly, the fears of Emperor Alexander now seemed justified. Few countries in Europe had suffered as Spain suffered, and few had brought down on Europe comparable disasters.

Among Spain's internal sufferings, the Russian government identified anarchy, destruction, insults to the throne and religion, the loss of rich territories in the New World, the dissipation of public wealth, the open preaching of subversive doctrines, and bans against subjects loyal to the sovereign. Not content with domestic transformation, the artisans of the troubles in Spain had spread revolution to other countries, compelling the allied powers to use military force to restore legitimate authority. In the Kingdom of the Two Sicilies and in Piedmont, beautiful lands desolated by war, sects had conspired against the tranquility of all European states. In other words, by the time the allies met in Verona, the revolution in Spain had become more radical, and so too had the 
great powers' understanding of legitimacy and restoration. Russia's condemnation of Spain's revolutionaries bemoaned the obligation of governments-an obligation imposed by the law of the peoples' salvation (salut) - to engage in rigorous surveillance, which in turn prevented them from pursuing more useful improvements. In Spain at least - if not also in Italy, Portugal, and Greece-the enlightened balancing of reform and repression had tilted in favor of repression. What Russia's monarchy failed to see, and what it would continue to ignore until the end of the old regime, was the unstoppable advent (or necessity) of vigorously contested participatory politics. For the moment, the inevitability of further change could be ignored in France, Germany, Italy, Portugal, and Greece, but not in Spain or Spanish America. ${ }^{66}$

By the fall of 1822 , the insurrection that had begun in Cadiz came to be seen as a deplorable example of the results of revolution. According to the Russian government, the events in Naples and Turin had endangered primarily Austria. The Spanish threat to France, however, affected every European power. Emperor Alexander accepted Montmorency's claim that the Spanish Revolution exposed France to imminent peril. He therefore stood ready to act in concert with France and the other allied courts, based on the proposals of the French foreign minister. Specifically, Russia's plenipotentiary received authorization to reach agreement on breaking diplomatic relations with Spain, defining the moral assistance that France currently sought, and stipulating within limits the material aid that France might demand, if compelled to use military force. Simply put, the interests of all Europe required suppression of the Spanish Revolution.

On 19/31 October 1822, the Austrian government responded to this new phase in the discussion by proposing concerted action in Spain. ${ }^{67}$ Approved by Russia, the Austrian proposal highlighted two questions that the allies needed to address. First was the danger to all Europe represented by the victory of revolution, and second was the crisis in political relations between France and Spain. The French government had explained its predicament to the allies, and although it hoped to maintain peace, the Spanish Revolution had the potential to force France to repel aggression. For this reason, the French government had asked the allies whether or not, in case of a just and necessary defense, France could count on their moral and material support. Austria, Prussia, and Russia had replied in the affirmative, a response that now required a more precise definition of the casus foederis and the reciprocal obligations to be assumed. To meet this need, the allied governments agreed to compose appropriate diplomatic transactions.

The Austrian proposal then turned to Spain's internal situation, where revolutionary anarchy, which also fueled civil war, challenged the efforts of the allied 
sovereigns to conserve social order. The language and attitude of the Spanish toward foreign countries had become so provocative that the European powers could no longer remain silent. Thus, the allies had asserted the right to discuss Spain collectively, thereby fulfilling their obligation to deliberate on the means to save Europe from the dangers posed by the triumph of the revolution. Not only France, but also all of Europe would benefit from the elucidation of common commitments that aimed to restore order on the peninsula. Although the great powers continued to hope that the victims and enemies of the revolution in Spain would have the courage to end the troubles, the Austrian proposal openly stated that relations between Spain and the allies depended on restoration of the king's legitimate authority. The king's continued captivity created a new claim or right that allowed the allied powers to decide the basis for future relations with Spain. Austria hoped, and Russia accepted, that any intervention would be pacific and take one of three possible forms. The five powers could adopt a common language by issuing a collective declaration or separate notes that were uniform in their principles and objective. France could rely on the four allies to address the current difficulties, even if they did not agree to participate in a common course of action. Or finally, one of the powers could communicate to the Spanish government the common position of the allies.

Russia's plenipotentiaries formally responded to the Austrian proposals at the conferences of 2I October/2 November $1822 .{ }^{68}$ The response conveyed Emperor Alexander's agreement that the allies should pursue a course of action designed to hasten the end of the revolution in Spain by encouraging the Spanish nation to "shake off the yoke of the factions oppressing them." Russia's representatives had received authorization to accede to the Austrian proposals and participate in the development of appropriate resolutions. These resolutions, combined with the commitments arising from France's propositions, would define allied policy toward Spain. Looking beyond broad statements of principle, the Russian government also urged the allies to consider (and specify) how each would proceed, if the representations of their diplomats in Madrid did not yield the desired result. From the start of the Spanish crisis, Alexander had wished to address the situation in concert with his allies. At the meetings in Verona, in light of Austria's reluctance to become materially engaged and Britain's continuing insistence on allied neutrality, Russia accepted the decision to send separate notes of uniform content to the Spanish government.

The Russian response did not explicitly mention the reservations of Austria or the opposition of Britain. By contrast, an unsigned secret memorandum, dated Is November I822 (NS) and listed in the Acts of the Conferences, expressed the 
Austrian fear that British separateness threatened the alliance, even though Britain remained free in its decisions and actions due to its direct influence over the peninsula (that is, its relations with Portugal). ${ }^{69}$ The memorandum also highlighted the agreement among the other great powers to support the Spanish king and end the revolution. The allies currently maintained diplomatic relations with the revolutionary faction in Spain, yet they also functioned as a "league of moral action" united in principle on the acceptability of defensive material action. In other words, the need to define a casus foederis in association with France was agreed to in principle, though the actual definition required more specifics. The memorandum also voiced concern about the weakness of the French government and the danger that a new revolutionary shock in France posed for all Europe. Finally, the memorandum reiterated the allies' hope that once they declared their collective readiness to break diplomatic relations with revolutionary Spain, British neutrality would become untenable. Britain would then be compelled to explain its position on preserving political peace between Spain and the allies, restoring order on the peninsula, and maintaining the alliance, "the dissolution of which could be brought about by an unforeseen difference between the course taken by the four continental Courts and that of England."

In conference minutes signed on 7/19 November 1822, the plenipotentiaries of Austria, France, Prussia, and Russia addressed ongoing worries about how the powers should respond, if the Austrian proposal for peaceful intervention in Spain failed..$^{70}$ The conference record identified the circumstances that might lead the courts of Austria, Prussia, and Russia to act with the court of France in a declared war or a war provoked by the current government of Spain. Two articles specified the conditions that would make such engagements obligatory. The first focused on three actions by the Spanish government that the allies would treat as the casus foederis for war: (I) a military attack by Spain on French territory or an act of the Spanish government that directly provoked rebellion among the subjects of one or another of the powers; (2) the declared downfall (déchéance prononcée) of the Spanish king or legal proceedings against him or members of his family; and (3) a formal act by the Spanish government that restricted the royal family's rights of legitimate succession. Article 2 of the minutes left open the possibility that additional unspecified developments might also be treated as the casus foederis. Any signatory could present a case to the allied governments, which then would consider whether or not the circumstances belonged to the class of casus foederis as foreseen and defined. The understanding reached on the casus foederis showed once again that the alliance of the great powers-including the Holy Alliance so often identified with Austria, Prussia, 
and Russia-did not aim to prevent political change or social reform in Europe. To the contrary, the peacemakers' definition of the casus foederis addressed the consequences of violent revolution, based on their experience of the French Revolution and Napoleonic conquests. The allies may have been willfully blind to the realities of emergent democratic politics, but they already had lived through, and now worked assiduously to prevent, the destruction of legitimate rulers and the spread of revolution by military aggression or direct external provocation.

In contrast to the Troppau protocol by which Austria, Prussia, and Russia had declared a common position on resolving the crisis in the Kingdom of the Two Sicilies, at the Verona conferences on $8 / 20$ November 1822 , the allies agreed not to issue a general protocol, but to send separate instructions to their ministers in Madrid. ${ }^{71}$ These instructions explained mutual concerns and principles of action and ordered diplomats to act in concert with colleagues. On $14 / 26$ November 1822, Emperor Alexander signed instructions to his chargé d'affaires in Madrid, Count Bulgari. Designed to provide a tableau of the Spanish Revolution and its consequences, which Bulgari was directed to propagate in government and elite social circles, the instructions began with a statement of the allies' determination to consolidate peace in Europe and prevent any action that compromised the current state of general tranquility. ${ }^{72}$ In March 1820 , a military revolt had forced the Spanish king to accept the liberal constitution of 1812 - "laws that the public reason of Europe, enlightened by the experience of centuries," greeted with outcries of disapproval. The allied governments had condemned these developments, and the Saint Petersburg government in particular had warned of the misfortunes that would follow. Based not on theories or principles but on the facts, the warnings and fears of 1820 now appeared prescient.

The allies assumed that the Spanish nation shared the wishes of its king and that the Spanish government sought to preserve the integrity of the monarchy. Consequently, the Verona decisions offered to Ferdinand VII an amicable intervention, designed also to restore Spanish authority in the empire's distant provinces, which provided so much wealth and power. According to the instructions, the March events seemed to justify rebellion in America by encouraging loyal provinces that suffered under the weight of revolutionary despotism to separate from the motherland. Regardless of causes and motivations, the anarchy of revolution threatened the prosperity of Spanish America. In conditions of disorder, public and private fortunes were decimated, rights were revoked, heavy contributions were levied, and ruinous loans were needed. Respect for the throne and religion already had been despoiled at the moment when the blind passions of the multitude replaced legitimate authority. For three years the allies had clung 
to the hope that the character of the Spanish people, who had stalwartly opposed revolution during the Napoleonic conquest, would prevail over the spirit of insurrection and allow the king to reclaim the legitimate rights of the throne.

But instead of being restored, the Spanish monarchy had fallen into ruin. Although Spain's people had endured six years of bloodshed in support of the monarchy, following the revolt of 7 July 1822 , the king and his family became captives. ${ }^{73}$ Civil war ensued, which produced higher levels of violence and larger numbers of victims. Nor did the conspirators limit their activities to Spain. They worked openly to spread rebellion, took credit for the revolutions in Italy, and currently threatened France. Emperor Alexander did not seek conflict with the Spanish government; however, the revolutionary menace could not be denied, and the radical doctrines on display could be seductive and fatal. Thus, despite the allies' desire for friendly relations with Madrid, they feared that the king lacked the freedom to end the civil war or prevent foreign conflicts. It remained for the Spanish government to remedy the situation by restoring the country to the honorable position in the European family that it had occupied in 1814 . This could be done only by defeating the revolution and returning to government based on ancient virtues and respect for religion.

Emperor Alexander further instructed Count Bulgari to communicate his good intentions toward the Spanish government. The allies claimed no right of intervention and did not seek to dictate laws to Spain or attack the country's independence. They did, however, want to see Spain freed from torment and bloodshed, and they hoped that the Spanish government would be reestablished as a wise and national administration. Currently, the revolution endangered the prosperity of Spain and the security of France. The revolutionary government in Madrid not only encouraged civil strife, but also prevented reconciliation with the colonies. Sadly, the allies no longer believed that the king would be able to reclaim his authority or restore social order. Because Ferdinand and his family had become virtual prisoners, the Spanish monarch was not free to work with the allies. As the instructions stated, only the men ruling in Madrid could accept the means being offered to lead Spain to a tranquil and glorious future. Thus, although the allies did not insist on any particular form of government, they clearly rejected the constitution of $\mathrm{I} 8 \mathrm{i} 2$ and wanted to see the authority of the king and religion restored.

A second dispatch, also dated 14/26 November 1822, explained to Count Bulgari how he should proceed in the present grave and perilous situation. ${ }^{74}$ The allies aspired to ameliorate the future of Spain, which implied persuading the Spanish nation and government to abandon the revolution. This tactic had 
proven effective in the Kingdom of the Two Sicilies, where the allies had reached agreement with King Ferdinand I to end the revolution. Yet evil as the consequences of the Spanish Revolution appeared to be, Alexander I and his allies did not expect their efforts to succeed: "In the tumult of the passions, the voice of reason is rarely heard." Assuming that the men who exercised power in Madrid refused to listen to reason, it nonetheless remained critically important to give the Spanish nation the opportunity, based on authentic documents, to hear the views of the allied courts. Diplomats such as Bulgari had therefore received instructions highlighting the losses to Spain caused by the March revolution, the captivity of the king and his family, and the intelligence that exposed how the artisans of the Spanish troubles aimed to incite revolt in France and other countries. Bulgari's assignment was to campaign against the current Spanish government, both among officials and in society, in order to weaken the party oppressing Spain and strengthen the one fighting for the country's deliverance. To that end, he was authorized not only to read to the Spanish foreign minister the allies' chronicle of the revolution and its consequences, but also to provide him with a copy of the document. If the government did not heed the advice of the intervening powers or respond within fifteen days, Bulgari should request the passports of the Russian legation and leave the country. The diplomats of Austria and Prussia received the same instructions, and although all were permitted to negotiate with the Spanish minister of foreign affairs, they could not alter the conditions for preserving diplomatic relations with Spain. ${ }^{75}$

The Verona instructions and the diplomatic maneuvering in Madrid failed to change Spanish policy. In January I823, Austria, Prussia, and Russia broke diplomatic relations with Spain, and at the opening of the French Chambers, Louis XVIII announced that his troops were ready to march. The actual invasion of Spain began in April, and by September the French army had restored royal rule. In October, King Ferdinand VII rescinded the amnesty he had granted in September, declared that in effect he had been a prisoner since 1820 , and renounced the constitution of $18 \mathrm{I} 2$, together with all laws passed under the revolutionary government. According to historians, after a period of repression in $1823-24$, the king pursued more moderate policies, and in 1827 French troops left Spain. The peacemakers of post-Napoleonic Europe won a temporary victory. Still, the Spanish Revolution exposed not only the intractable political schism between liberals and royalists, but also the ease with which political conflict could degenerate into civil strife, guerilla warfare, and atrocities on all sides. ${ }^{76}$ Among the peacemakers of 1814 , 1815 , and 1818 , political conditions in Spain caused palpable confusion. 


\section{Whither European Peace?}

Just one day before Emperor Alexander departed Verona, the courts of Austria, Prussia, and Russia signed a circular on Italian affairs that summed up the decisions taken in response to insurrections in Italy, Greece, and Spain..$^{77}$ The three governments viewed the circular of $2 / 14$ December 1822 as a follow-up to instructions issued in May I821, at the close of the Laibach conferences, and as a common instruction that would be sent to their diplomatic agents abroad. The circular began with the military occupation of Piedmont, which, based on an agreement with the king of Sardinia-Piedmont, would end by 30 September $1823 .^{78}$ With respect to the Kingdom of the Two Sicilies, the allies and King Ferdinand I had agreed to reduce the army of occupation to 17,000 troops as quickly as possible. ${ }^{79}$ As the circular recalled, in Laibach the three sovereigns also had expressed the hope that the intervention in Italy, which they called a painful duty imposed on them by necessity, would be brief and that another would never be necessary. ${ }^{80}$ The monarchs further noted that despite their intentions, allied actions in Italy had produced false alarms, hostile interpretations, and sinister predictions designed to misdirect the opinion of the peoples. ${ }^{81}$ The allies had acted not out of secret ambition or calculated interest, but out of the need to resist revolution and prevent the countless disorders, crimes, and calamities that rebellion had inflicted across Italy. In other words, "the sole objective of the thoughts and efforts of the Monarchs" was to restore order and peace and to provide legitimate governments with the assistance they had a right to demand. The sovereigns of Italy remained independent, charged by Divine Providence to ensure the security and tranquility of their peoples, and the three allied monarchs wanted nothing more than to restore power to these princes. Indeed, they characterized their decisions for the relief of Italy as the fulfilment of the alliance's very purpose.

But soon after the allies reached agreement on action in Italy, another complication emerged. The revolutionary genie spread from Spain and Italy to the Ottoman Empire. The allies agreed that all of the recent revolts arose from the same evil ( $\mathrm{mal}$ ). The revolutionaries might invoke different pretexts, but the origin, substance, and language of the evil were identical. The men who directed the movement likewise sought to divide the powers and neutralize the forces that could oppose them. In response, the three monarchs had decided "to repel the principle of revolt in whatever place and under whatever form it appeared." During this momentous period for the alliance, the five great powers (Austria, Britain, France, Prussia, and Russia) had exchanged numerous confidential 
communications, and at the conferences in Verona, they had consecrated and confirmed the supposed unanimity already achieved. In December 1822, the three sovereigns who had signed on to intervention in Italy also still expected to overcome the obstacles preventing the fulfilment of their wishes in relation to the Eastern Question.

The circular then turned to the deplorable situation on the western peninsula of Europe. ${ }^{82}$ Spain shared the misfortune of countries that embraced unfortunate means to seek out the good (le bien). Thus, a group of disoriented and perverse men presented the evil of revolution as a good deed (bienfait), calling it "the triumph of the century of Enlightenment," "the necessary and happy fruit of the progress of civilization," the means to support and bring about civilization, and the motor of a fertile patriotism. If civilization had as its objective the destruction of society, and if military forces could with impunity seize control over empires-the internal and external peace of which they were supposed to guarantee-then, yes, the Spanish Revolution deserved the admiration of the ages, and the military insurrectionists offered a model for reformers. But this was not the reality. Truth demanded its rights, and Spain represented a sad example of the consequences that resulted from violating the eternal laws of the moral world.

Conditions in Spain did indeed look bleak. Legitimate power, currently in chains, was being used to overturn all rights and legal liberties. Arbitrariness and oppression assumed the form of law, all classes of the population appeared agitated, and the kingdom suffered from convulsions and disorders. As civil war consumed the resources of the state, Spain's rich colonies justified their own emancipation with the same maxims proclaimed by the mother country in establishing public law. The misfortunes afflicting a loyal people explained in turn why countries in immediate contact with the peninsula had become worried, troubled, and confused. The current disorganization of Spain threatened the conservative principles that served as the basis for the European alliance. In a situation that became more alarming each day and that posed so many dangers to others, the monarchs could not remain tranquil spectators. Precisely because the presence of allied diplomats in Madrid implied tacit approval for the acts of a faction - a faction that would do anything to preserve its deadly power-the monarchs' missions had received orders to leave Spain.

The decision to break diplomatic relations with Spain would prove to Europe that the allies had not retreated from the "resolve sanctioned by their intimate conviction." The monarchs had agreed to act, based on their friendship toward the Spanish king and their interest in the well-being of the Spanish 
nation, which more than once in its history had been distinguished by its virtues and grandeur. The allied transactions affecting Spain adhered to the principles that guided the monarchs as they addressed all the great questions of order and stability exposed by recent events. To refute calumnies leveled against them, the monarchs pointed to the evidence of their deeds, the loyalty and benevolence of their intentions, and the force and cohesion of their union. British neutrality and the absence of a general Verona protocol belied the claim of unity, though the acceptance of a possible French intervention in Spain could be seen as proof of a stronger and more broad-based alliance. Still, in the tone of the Verona circular one detects growing frustration and a trace of desperation. Could the moderate reformism of the peacemakers constrain revolutionary war?

The monarchs, the circular continued, wished only for peace. All Europe should therefore recognize that the course pursued by the allies remained fully consistent with the independence of governments and the interests of the peoples. The monarchs viewed as enemies only those who conspired against legitimate authority and misled others to follow them into the common abyss. Indeed, peace among states, even when well established, brought no benefit to society, as long as spirits remained agitated. The circular attributed the current agitation to the perfidious suggestions and criminal endeavors of one faction that wanted only revolution and upheaval. The leaders and instruments of this faction, whether operating in the open or in the shadows to organize sinister plots and to poison public opinion, continued to torment the peoples through the propagation of a somber and mendacious account of current conditions. According to the revolutionaries' tableau, governments did not prosper, improvements did not succeed, and trust among men no longer existed. To render these odious plots powerless, the monarchs had set about the noble task of destroying the weapons that the factions could use to disrupt the tranquility of the world.

The closing section of the circular instructed the diplomats of Austria, Prussia, and Russia to promote its content among the governments to which they were accredited. There could be no true happiness for the nations without calm and stability. Nor could the three signatories to the circular achieve their goals without sincere and constant support from all the governments (of Europe). The monarchs called for this assistance "in the name of their primary interests,... in the name of the conservation of social order, and in the name of future generations." They recognized the great truth that their power rested on a sacred trust, for which they must account not only to their peoples, but also to posterity. 
Numerous documents of the era emphasized the obligation to implement the laws and ensure good governance. In this instance, the Verona circular highlighted the monarchs' responsibility to deliver their peoples from the errors and misfortunes for which they as rulers might have prepared the way. The monarchs liked to believe that they would find in all those called to exercise supreme authority, under whatever form (of government), true allies who respected the letter and positive stipulations of the acts constituting the basis of the European system. As important as the spirit and principles of the European system were the legal obligations defined in the treaties. The circular ended with a simple affirmation of the monarchs' determination to use all the means that Divine Providence had put at their disposal for the welfare of Europe.

The revolutionary situations in Piedmont and the Kingdom of the Two Sicilies had been effectively addressed, if not fully resolved. Portugal belonged to the British sphere, and France, the Verona documents implied, would take the lead in Spain. At the same time, the allies expected, though ultimately failed, to define a common position on Greece. With respect to Spain's American colonies, the great powers, except for Britain, also failed to admit the inevitable trajectory toward independence. By 1825 the emancipation of Latin America was all but completed ${ }^{83}$ Emperor Alexander died in December 1825, and Russia experienced its first modern revolt, the Decembrist Rebellion, which aimed to restructure social and political arrangements. ${ }^{84}$ In 1830 France returned to the path of revolution, Belgium broke away from Holland, and Poland rebelled against Russian rule. By 1848 revolution again engulfed much of Western and Central Europe: France, Italy, the German states, and the Austrian Empire. ${ }^{85}$

The peace treaties of 1814,1815 , and I8I8 remained broadly operative, but the vision of European order embraced by the peacemakers could not contain the movements of peoples or offer satisfactory answers to the radical and ethno-nationalist ideologies of the day. Recent scholarship praises the peacemakers for establishing diplomatic practices that until I9I4 prevented pan-European war and that even after the Great War continued to provide a foundation for European unity. Unlike some present-day proponents of the European idea, Jürgen Osterhammel offers an understated and more realistic appraisal of how European unity worked. After the Congress of Vienna, he notes, the European state system no longer produced "fragile balances more or less automatically but required political management structured by a basic set of both manifest and unspoken rules." ${ }^{" 6}$ As the preceding chapters argue, the idealized narrative of European integration does not adequately account for Russia's experience of or contribution to European peace. In the Restoration era, the Russian Empire and 
its monarch stood at the center of European society, yet in the Crimean War of 1853-56, Britain and France fought on the side of the enemy, and the European alliance ceased to represent the principal pathway to peace. ${ }^{87}$ The separate alliances that the Russian government long had claimed to oppose returned to Europe's diplomatic chessboard. 